\title{
Maria Mulet, escriptora i docent (1911-1982)
}

\author{
[Maria Mulet, writer and teacher (1911-1982)] \\ EnCARna Villafranca Giner \\ Universitat de València \\ encarnablai@gmail.com
}

\begin{abstract}
RESUM: Els estudis sobre les contribucions de les escriptores valencians de la postguerra són més aviat escassos, però a poc a poc s'avança en aquesta matèria. En el present treball tractem de poesia escrita per dones al llarg de la postguerra i, concretament, començarem l'estudi de l'obra de Maria Mulet, nascuda el 1911 i que va ser una de les dones silenciades que van experimentar un canvi social després de la guerra i que en van patir les conseqüències. Mestra i escriptora que sabia molt bé aprofitar tots els recursos que havia de subministrar per a escriure i treballar, va escriure en valencià i en castellà, a més de ser creadora de lectures per a utilitzar-les a l'aula, en un moment en què l'aprenentatge del valencià era impossible.
\end{abstract}

PARAules ClaU: Maria Mulet; postguerra; poesia, valencià, pedagogia.

AвSTRACT: Studies on the contributions of postwar valencian writings are more scarce, but little by little progress is made in this matter. In the work we deal with poetry written by women throughout the postwar period and specifically we will begin the study of the work of Maria Mulet in 1911. Maria Mulet was one of silenced women, born at the beginning of the century, who experienced a social change after the war and suffered the consequences. Teacher and writer she knew very well how to take advantage of all the resources she had to supply to write and work. He wrote in valencian and spanish, in addition to creating readings for use within the classroom at time when learning valencian was impossible.

KEYWORDs: Maria Mulet; postwar; poetry, valencian, pedagogy. 


\section{Introducció}

Els estudis sobre les aportacions de les escriptores valencianes de postguerra són més aviat escassos, encara que ja donaven compte d'algunes d'elles els treballs de Vicent Simbor i Ferran Carbó (1993) o els reculls poètics com els de Joan Fuster (1980).

Ara, però, disposem d'una bibliografia augmentada per les aportacions realitzades entre d'altres per Maria Lacueva (2013) i centrades explícitament i exclusiva en la poesia escrita per dones al llarg de la postguerra.

Respecte al concepte poesia escrita per dones o poesia de dones, cal tenir en compte i aclarir que és un terme que Maria Payeras (2009) matisa, ja que addueix que el segon terme del sintagma nega el primer i, per tant, aquesta enunciació resulta pejorativa. Tot i que existeix una necessitat d'aprofundir en la poesia escrita per dones com a creadores, aquesta no s'ha de fer ni a banda ni al marge dels poetes masculins, sinó com una manera de posar en relleu aquelles que per qüestions socials se'ls ha estat silenciant.

Així les coses, trobarem com «les dones» no funcionaven al marge de la societat, ni dels moviments literaris, ni dels esdeveniments poètics, ni de les novetats literàries, l'arrelament a la societat... igual que els homes sinó que hi eren ben presents però silenciades fins i tot ben entrats els anys setanta, com ho demostra l'antologia de poesia jove d'Amadeu Fabregat Carn fresca (1974) on no apareix cap dona tot i l'existència de joves poetes dones.

El silenci de la veu de les dones és on es troba la diferència, un punt de divergència entre la poesia escrita per homes i l'escrita per dones. Les dones necessiten entendre el perquè viuen silenciades, perquè pel fet de ser dones ocupen un lloc diferent sempre per sota dels homes i per aquest motiu el jo poètic afig en major o menor mesura la reflexió sobre la condició del seu gènere, la reflexió en l'autorepresentació poètica com a dones en les seues pròpies obres en el context social, polític i cultural que li ha tocat viure, cosa que els homes no tenen necessitat de construir ni analitzar. Els homes no necessiten analitzar la seua construcció social com a gènere.

REVISTA VALENCIANA DE FILOLOGIA / IV (2020) p. IO9-I33

ENCARNA VILLAFRANCA GINER

Maria Mulet, escriptora i docent (1911-1982) / I Io 
Per tant, siga com siga, la poesia feta per dones té un afegit valor contextual, el fet de ser dona en una societat amb uns valors determinats, en una època determinada, $\mathrm{amb}$ una biografia exclusiva de cadascuna i amb una recepció marcada pels paràmetres literaris eminentment masculins, si és que arribaven a publicar. És, per tant, que els treballs sobre dones escriptores o poetes són d'una complexitat més gran que la de l'altre gènere però que no s'han d'excloure i ni estudiar-les al marge dels cànons estètics marcats pels estudis literaris ja consolidats, tot i que la història de la literatura s'haja construït sobre paràmetres estrictament androcèntrics. Elles són filles del seu temps, de la història i com a creadores són intel-lectuals que pensen i creen com els homes tot $\mathrm{i}$ el seu condicionant de gènere. Cal implementar investigacions que donen veu a les dones creadores i que les situen pel seu valor individual al costat dels seus congèneres.

Nosaltres en aquest article ens centrarem en Maria Mulet, escriptora que es troba situada dins el context de postguerra. Un context difícil en el qual la dona va quedar en una situació d'inferioritat respecte a la figura masculina i principalment aillada dins l'àmbit familiar, allunyada de la presència pública. Només dues ocupacions eren tolerades per a una dona en l'època i amb les quals tenia presència pública. Aquestes foren la de mestra i la d'infermera, totes dues fadrines.

\section{Breus apunts contextuals}

L'1 d'abril de 1939 començava per a la nostra cultura una nova etapa marcada per un règim centralista que deixà molt clar el seu missatge i abolí les nacionalitats històriques de l'estat espanyol i totes les entitats culturals marcades pel caràcter nacionalista que havien intentat sobreviure des de l'època de la Renaixença.

Però al País Valencià trobem un cas excepcional, a València el règim va permetre que Lo Rat Penat (LRP), entitat conservadora que des d'un primer moment s'havia mostrat adepta al règim, continuara les seues activitats.

REVISTA VALENCIANA DE FILOLOGIA / IV (2020) p. IO9-I33

ENCARNA VILLAFRANCA GINER

Maria Mulet, escriptora i docent (1911-1982) / I I I 
El motiu d'aquesta permissivitat fou simplement que Lo Rat Penat quedà relegat a unes manifestacions folklòriques en pro del govern centralista instaurat el 1939.

Santi Cortés (1995: 276) divideix la trajectòria de LRP en dues etapes:

-Col-laboracionista (1939-1948): època en la qual es redueix la seua activitat a la mera realització dels Jocs Florals anuals que no tenien cap altra finalitat que mostrar la seua adhesió al règim.

-Obertura (1948-1975): que comença amb el nomenament, el 1948, de Manuel González Martí com a president de LRP, el qual oferí a Carles Salvador la direcció de la Secció de Literatura i Filologia. Amb Carles Salvador al capdavant s'organitzaren els famosos cursos de llengua i literatura que com indica Simbor (1983: 87):

La transcendència dels cursos de la rejovenida societat de la mà de Carles Salvador és extraordinària, imprescindible, clau. Tots els valencianistes de més de trenta anys han passat pels cursos orals o s'han inscrit en els cursos per correspondència per aprendre la seua llengua. Tota la generació valencianista de Postguerra s'ha format en els cursos organitzats per Carles Salvador que per la seua dedicació ininterrompuda al llarg de la seua vida a la defensa i recuperació nacional dels valencians ha estat l'home pont, l'home imprescindible entre l'abans i el després de la guerra.

Així, en aquest segon període, trobem, d'una banda, els adeptes al règim però amb una mentalitat oberta i reflexiva amb la realitat històrica i cultural del nostre poble com ara González Martí, i de l'altra, aquells que segueixen la línia de Carles Salvador, que, sense ser un col-laborador de les propostes oficials, es feu càrrec de la Secció de Literatura i Filologia de LRP. A partir d'aquest moment començà a obrir-se una escletxa dins la societat valenciana per on «salvar els mots» no amb la normalització del valencià com a llengua d'ús públic però sí amb la seua normativització, que es feu prenent com a base les Normes de Castelló de 1932, que havien estat unes normes de consens de totes les vessants ideològiques de la societat valenciana dels anys trenta.

REVISTA VALENCIANA DE FILOLOGIA / IV (2020) p. IO9-I33

ENCARNA VILLAFRANCA GINER

Maria Mulet, escriptora i docent (1911-1982) / I I 2 
A més a més, en aquesta època es possibilitaren una sèrie de publicacions periòdiques on trobem creacions en prosa o vers d'autors i autores lligades a LRP. Aquestes publicacions són Almanaque para las Provincias (APP) i Pensat $i$ Fet (PiF). Aquesta última revista com indica (Cortés 1995: 315) fou: «una revista fallera amb una preocupació estimable per fer literatura d'alta volada amb el tema de les falles».

Les controvèrsies lingüístiques nascudes al si de LRP i que van afectar diverses publicacions en èpoques posteriors no s'havia produït. L'any $1968 \mathrm{PiF}$ publica un article escrit per Antoni Igual Úbeda en aquests termes:

Heus ací que el dret del poble a emprar la llengua materna — aquella que cada un va aprendre al temps de la seua més tendra edat, als braços de la dona que el va infantar- és un dret natural que cap constitució política del món ha permés prohibir i que la dràstica imposició de cap conqueridor, al travers ( $\mathrm{sic}$ ) de la Història, ha intentat imposar. Mes quan aquesta iniciació de la llengua materna careix (sic) d'una escaient continuació a l'escola, quan el nen es veu obligat a iniciar, llavors, l'aprenentatge d'un idioma nou, el seu esperit sofreix una greu violència que deixarà tristes petjades, encara que no tinga cap manifestació exterior. Per açò la Unesco recomana a tots els països a ella adherits que l'ensenyança elemental i primària es done amb la llengua materna $[. .$.

Aquesta idea manifestada el 1968 enllaça amb les idees expressades per Carles Salvador als anys trenta, qui ja havia lluitat en defensa de l'idioma així com de la introducció de les noves tendències pedagògiques i proposà un nou model d'escola on l'alumne s'educara en la seua llengua materna i esdevinguera vertader protagonista de l'ensenyament, tal com explica Simbor (1982).

I en aquest context trobem Maria Mulet. En aquesta segona etapa de LRP, sota el mestratge de Carles Salvador, la nostra autora aprén la llengua i la literatura del nostre poble tot i que com a escriptora s'estrena el 1948 amb un poemari en castellà Arpa suave, la qual cosa analitzarem més endavant.

REVISTA VALENCIANA DE FILOLOGIA / IV (2020) p. IO9-I33

ENCARNA VILLAFRANCA GINER

Maria Mulet, escriptora i docent (1911-1982) / I I3 


\section{Maria Mulet}

A hores d'ara comptem, com hem dit abans, amb una bibliografia recent sobre el tema que ens ocupa i més concretament, a través dels estudis realitzats per Lacueva (2013) qui identifica tres grups d'escriptores agrupades per un factor generacional al qual afig un factor contextual com fou el de la Guerra Civil. Lacueva estableix aquests tres grans grups i analitza les següents escriptores:

1. Les escriptores nascudes entre 1890 i 1905: que patiren la dictadura durant la maduresa. En aquest punt situa Anna Rebeca Mezquita Almer (1890-1970) i Maria Ibars i Ibars (1892-1965).

2. Les nascudes entre 1906 i 1920: les que visqueren una frustració. En aquest període analitza Matilde Llòria (1912-2002) i Beatriu Civera (1914-1995).

3. Les nascudes entre 1921 i 1935: que maduraren en un clima asfixiant.

Pel que fa a les més joves, situa Maria Beneyto i Cuñat (1925-2011), Carmelina Sánchez-Cutillas (1927-2009) i Maria Mulet (Albalat de la Ribera, 1930-1982).

Maria Mulet és situada per Lacueva (2013) en el tercer grup d'escriptores de postguerra per la seua data de naixement. Ara bé, aquesta data és incorrecta. La data de naixement de 1930 apareix per primera vegada a la Gran Enciclopedia de la Región Valenciana i es reprodueix de manera sistemàtica en moltes altres referències com el Diccionari bibliogràfic de dones. La data real del naixement de Maria Mulet fou el 1911, i per tant, caldria situar-la segons la classificació de Lacueva en el segon grup d'escriptores.

En realitat, tal com consta a l'Arxiu Municipal d'Albalat de la Ribera, Maria Amèlia Mulet Mulet, coneguda com Maria Mulet, va nàixer a Albalat de la Ribera el 8 de febrer de 1911 i va morir a Cullera el 16 de setembre de 1982. Fou filla d'una família benestant amb fortes inclinacions culturals. Maria Mulet estudià magisteri i tenia formació musical i artística. Tocava el piano, la pintura i el dibuix eren una de les seues tasques habituals juntament

REVISTA VALENCIANA DE FILOLOGIA / IV (2020) p. IO9-I33

ENCARNA VILLAFRANCA GINER

Maria Mulet, escriptora i docent (1911-1982) / I I4 
amb l'escriptura i la lectura. Fou neboda del pintor Vicent Mulet ${ }^{1}$ i al llarg de las seua vida es relacionà amb d'altres pintors que tenia per amics i que collaboraren en la publicació de les seues obres com Pedro de Valencia. També cal remarcar la seua amistat amb Sanchis Guarner i Nicolau Primitiu.

Va participar en els cursos de LRP com a alumna primer i com a mestra d'infants després i aquesta institució li publicà alguns dels seus llibres en la nostra llengua.

Els seus referents literaris foren molt diversos en funció de cada època de la seua vida. Entre les seues lectures hem pogut trobar referències a Blasco Ibáñez, Juan Ramon Jiménez, Antonio Machado, Carles Salvador, Maria Ibars, etc. No es va casar mai i va viure sempre amb la seua germana Ángeles, qui era pintora. La primera destinació que se li coneix com a mestra fou Banyeres de Mariola i d'allí va passar a Cullera, on va exercir com a mestra de l'Escuela de Orientación Marítima tota la seua etapa com a docent. Morí a Cullera prop de la mar que tantes vegades va exaltar als seus poemes.

\section{Una aproximació a l'obra de Maria Mulet}

Analitzar l'obra de Maria Mulet no és gens fàcil igual que no ho foren les circumstàncies històriques que li tocà viure. A hores d'ara no podem saber si el motiu pel qual optà per unes solucions estètiques, temàtiques, lingüístiques etc. fou per ideologia o per les circumstàncies del moment. El que sí que podem observar és, d'una banda, el bilingüisme de la seua obra i, de l'altra, dos tipus de lector model, un públic adult a qui destina les obres de creació amb un objectiu eminentment estètic, $i$ un altre de jove a qui destina les seues obres de caràcter pedagògic.

1 El pintor d'Albalat Vicent Mulet (1894-1955), de notable influència en la pintura valenciana dels anys vint, havia residit a París i a Londres. El 1940 regressà a Albalat, i al seu entorn —atret pel seu prestigi- es congregà un cercle d'artistes que solia reunir-se les vesprades de diumenge per a parlar d'art i de qüestions filosòfiques en general.

REVISTA VALENCIANA DE FILOLOGIA / IV (2020) p. IO9-I33

ENCARNA VILLAFRANCA GINER

Maria Mulet, escriptora i docent (1911-1982) / I I 5 


\subsection{Producció en castellà}

La producció en castellà d'aquesta autora és prou considerable, si la comparem amb el nombre d'obres publicades en valencià, però cal tenir en compte que en les dates de publicació de les seues obres en castellà, en la immediata postguerra, no es considerava ni de bon tros la possibilitat de la publicació d'obres escrites en valencià, les quals havien estat retirades dels aparadors de les llibreries, i la publicació en llengua autòctona es reduïa a simples manifestacions folklòriques. Però el circuit literari «en la lengua oficial» tampoc no gaudia de més llibertat, ja que la publicació de qualsevol obra havia d'estar sotmesa al control de la censura i la dotació de la corresponent llicència eclesiàstica.

Amb aquest panorama les primeres produccions de Maria Mulet concorden amb la sintonia literària del moment, la realització d'una poesia paisatgística i ornamental que no qüestiona el sistema ni posa de manifest la realitat sinó que s'hi inscriu dins i treballa els cànons clàssics imperants. Un tipus de poesia d'arrelament al medi i al context sociopolític del moment.

La primera obra que publicà fou un llibre de poemes titulat Arpa suave ${ }^{2}$ (1948), amb dibuixos de Vicent Mulet i prologat per Joan Lacomba, qui va dir de Maria Mulet:

[...] recrea pictóricamente con tan solo el don de la palabra, que domina y siembra en maravillosas imágenes, emoción de paisaje y sentimiento de vida. Y desde esa Ribera Baja, dulce y soñolienta del Júcar, por la que sosegadamente pasa el río, caudal de vida que escapa y «va a dar en el mar, que es el morir.

2 Aquest llibre porta una justificació de la tirada: «De esta primera edición del libro Arpa suave, de María Mulet, se han impreso dos ejemplares en papel Ingrés, con filigrana Guarro, signados con las letras A y B, no venales, treinta y cinco ejemplares en papel Ingrés agarbanzado, con filigrana Guarro, firmados y numerados a mano por el autor (sic) del 1 al 35 para los subscriptores de honor y trescientos ejemplares en papel registro blanco numerados del 36 al 335 que forman la edición original». L'exemplar número 12 fou per a Nicolau Primitiu, a qui li va escriure la següent dedicatòria: "Con la admiración, cariño y respeto que merece el hombre sabio y también poeta. Cordialmente».

REVISTA VALENCIANA DE FILOLOGIA / IV (2020) p. IO9-I33

ENCARNA VILLAFRANCA GINER

Maria Mulet, escriptora i docent (1911-1982) / I I6 
Aquestes paraules de Lacomba resumeixen perfectament no sols les característiques estètiques del llibre que prologa, sinó també el conjunt de l'obra posterior de l'autora marcada per un arrelament a la terra que l'envolta, que es manifesta a través de la poesia pairalista que conreà. Arpa suave és un poemari dividit en tres parts: «Prólogo»; «Estampas de vírgenes y de niños», on recrea poèticament la vida quotidiana dels personatges nadalencs i apareixen poemes en forma de cançó popular; una segona part, «El cielo y el río», dedicada al seu oncle Vicent Mulet d'on hem extret els següents versos:

Aquellos días...

Otoño en la Ribera,

Color y cielo,

Acorde de las horas,

Milagro eterno... ${ }^{3}$

La tercera part, que porta per títol «La voz en el viento», són uns poemes d'exaltació pel descobriment del medi natural

«Romance de enamorada»

Riberas, riberas verdes

Aquelles que el Júcar riega.

Si yo pudiera cantar

En verso que fueran sendas,

Por las que van los trigales,

Por las que van las adelfas

Y los campos siempre alegres,

$\mathrm{Y}$ las frondas verdinegras,

¡que bien sabían mis coplas

Hechas de voz de ribera!

3 Arpa suave, p. 59.

REVISTA VALENCIANA DE FILOLOGIA / IV (2020) p. IO9-I33

ENCARNA VILLAFRANCA GINER

Maria Mulet, escriptora i docent (1911-1982) / I I 7 
Posterioment, publica Contactos (1950), un poemari en cinc parts, on el paisatge de Banyeres de Mariola i la serra és ben present. És un poemari que transmet enyorança de les muntanyes i la natura que l'envolta, Donde haya sol (1963) segueix la mateixa línia. En definitiva, són poemaris en què se'ns mostra una visió particular i intimista de la natura, la personificació dels elements naturals, l'epítet, la sintaxi simple i les imatges plàstiques els inunden.

La poesia de caire religiós està ben present en l'obra de Maria Mulet Gloria a Dios, Poemas de navidad ${ }^{4}(1957)$ és un poemari en què s'exalten les excel-lències de la Mare de Déu i el Nadal, i amb es qual l'autora vol fer oblidar la realitat quotidiana.

Amor, la misma palabra (1969) fou l'única novel-la publicada per l'autora en la qual, mitjançant la tècnica del fulletó, analitza els típics problemes matrimonials que s'agreugen per la falta de comunicació i semblen aparentment abocats al fracàs. La comunicació i el respecte entre la parella susciten l'única resolució als conflictes plantejats.

En 1959 publicà Somos amigos, lectures infantiles. És un llibre que barreja prosa i poesia. Aquestes es conjuguen per a donar forma a un llibre de lectures infantils carregades d'una gran força didàctica que li van permetre guanyar un premi atorgat pel Ministerio de Educación y Ciencia. El 1959 se'n publicaren 6.000 exemplars i el 1963 se'n va imprimir una nova tirada de 135.000 .

També cal esmentar Las apuestas y el perro Kay (1970), una narració juvenil que intenta emular les històries protagonitzades pels personatges de The Famous Five creats per Enid Blyton entre els anys 1940 i 1960.

\subsection{Producció en valencià}

Qüestionar-se la trajectòria intel·lectual de Maria Mulet, i sobretot el pas decisiu que la feu escriure en valencià, és complicat per la mancança d'una informació directa la qual no ens permet de fer cap tipus d'afirmació i sols

4 El Nadal i la Mare de Déu seran, al llarg de la seua trajectòria poètica, uns temes recurrents tant en la poesia escrita en castellà com en valencià.

REVISTA VALENCIANA DE FILOLOGIA / IV (2020) p. IO9-I33

ENCARNA VILLAFRANCA GINER

Maria Mulet, escriptora i docent (1911-1982) / I I 8 
podem extraure de l'observació de la seua obra i d'unes notícies aparegudes a la premsa l'any 1976 amb motiu de la publicació del llibre Nadal al cor, unes conclusions que ens aproximen al pensament valencianista de Maria Mulet.

Maria Mulet realitzà, l'any 1967, una conferència en l'acte de cloenda dels cursos de Llengua i Literatura de Lo Rat Penat i des d'aleshores, segons declarà ella mateixa al diari Las Provincias el 18 de desembre de 1973: "estudio todos los días valenciano». I a més, també declara que escriu en valencià perquè:

[...] los niños buscan especialmente los libros en valenciano, lo tengo observado. Cuando en ellos llegan a las palabras que conocen las reciben como un regalo, y van buscando más y su horizonte verbal se va ensanchando. En todos los libros pongo un vocabulario que les ayuda en esta última tarea.

Però ja abans Maria Mulet havia mostrat els seus coneixements del valencià des de la revista fallera Pensat $i$ Fet, amb la qual col-laborà en tres ocasions als anys cinquanta amb tres composicions poètiques sobre la festa josefina: «Dia de Sant Josep» (1951), «Cremà» (1952), «Falles!» (1955). Són tres poemes on comparteix pàgina amb Carles Salvador, Joan Lacomba, Maria Ibars, Matilde Llòria i E. Duran i Tortajada.

A més, el curs 1970-1971 fou presidenta dels cursos de Llengua i Literatura de Lo Rat Penat. En aquest any les publicacions de LRP editen Veus de Xiquets.

La valencianitat de Maria Mulet, doncs, es troba íntimament relacionada amb l'herència valencianista de Carles Salvador, a qui admira i té present com un gran mestre.

4.2.1 Poesia

4.2.2.1. Col-laboracions

-Anuari faller: Pensat i Fet (PiF) (1951, 1952, 1955).

L'anuari Pensat $i$ Fet, escrit en la seua totalitat en valencià, fou permés pel règim pel seu caràcter anual, festiu i d'arrel regionalista, però aquests fets

REVISTA VALENCIANA DE FILOLOGIA / IV (2020) p. IO9-I33

ENCARNA VILLAFRANCA GINER

Maria Mulet, escriptora i docent (1911-1982) / I I9 
no resten importància a la vàlua històrica, ja que es preocupà per la normativa i puresa lingüístiques, i més com diu Cortés (1995: 315): «PiF fou una revista fallera amb una preocupació estimable per fer literatura d'alta volada amb el tema de les falles».

Maria Mulet publicà a la revista Pensat i Fet al costat de noms com Maria Ibars, Carles Salvador, Matilde G. de Llòria, E. Duran i Tortajada..., tots ells valencianistes insignes i revitalitzadors de la nostra cultura.

Les colllaboracions de Maria Mulet consten de composicions monotemàtiques mostren una visió folklòrica del dia de Sant Josep una mica personalitzada a través del tractament de la natura, ja siga durant el dia com a la nit ${ }^{5}$.

\begin{abstract}
Amaneix i la llum porta olor del cel dilatat; blaus fins al camp altra volta tornant en verds i daurats com si fóra llum de perles que elles sols van revallant.
\end{abstract}

Amaneix. Porta la brisa Poms de flor en un esclat: Ara volten rialleres Omplint de perfum extrany Les hores més peregrines Que se desvetlen brollant.

Amaneix. És un somni? Els àngels van abaixant Somrients, com a carícies, Entre rumors encantats.

Estrenyem el cor, que calle...

5 Els poemes s'han reproduit tal com van ser editats.

REVISTA VALENCIANA DE FILOLOGIA / IV (2020) p. IO9-I33 ENCARNA VILLAFRANCA GINER Maria Mulet, escriptora i docent (1911-1982) / I 20 
Després recem al bon Sant.

«Per la gràcia i pel dia

Que tu portes endolcint...»

«Dia de Sant Josep» (1951)

Jugaven les estrelles

Amb el mant que la nit s'enrotlla

I dient a tota veu:

A revolar, ensòmits,

A revolar...

I se besaven les paraules més dolces

En fugida graciosa:

Cançó, nostàlgia, anhel,

Desig, ales, perfum...

(Cada estrella està ací,

és un miracle renaixent de l'amor

a la nostra terra

en esta nit ansiosa.

Cada estrella està ací...

Que no se n' assabente el cel

puix que ploraria).

Jugaven les estrelles

«Cremà» (1952)

-Llibres de festes de Cullera: Cullera, fiestas a la Virgen del Castillo (1974 i 1976).

Tractar la producció de Maria Mulet als llibres de festes pot resultar una mica agosarat per la suposada mancança de qualitat literària d'aquests i l'entorn folklòric i populista en el qual estan emmarcats.

REVISTA VALENCIANA DE FILOLOGIA / IV (2020) p. IO9-I33

ENCARNA VILLAFRANCA GINER

Maria Mulet, escriptora i docent (1911-1982) / I 2 I 
Els estudiosos deixen de banda aquest tipus de composicions perquè les consideren literatura de baixa qualitat estètica. Segurament tindran raó en alguns casos, però en una cultura no normalitzada com era la nostra amb la trajectòria cultural tantes vegades interrompuda pels motius historicopolítics no podem deixar de banda cap manifestació literària per tal d'estudiar-la i posar-la en valor, si en té.

Maria Mulet participava de la quotidianitat de Cullera, on va viure fins la seua mort, i ho demostra des de les pàgines dels seus llibres de festes amb unes composicions poètiques en valencià que resultaven ben dignes. Aquestes són juntament amb la prosa del cronista local, Francesc Giner també professor dels cursos de LRP, les úniques manifestacions escrites en valencià a Cullera. En aquest sentit Fresquet (1996: 173) assenyala: «Els llibres de festes constituïen i encara ho fan, un marc per a la publicació de treballs literaris o estudis de caràcter local que normalment no transcendeixen d'aquest àmbit».

El fet de no transcendir l'àmbit local no implica la mancança de qualitat o d'interés per la creació literària i estètica en una època en que la llengua oficial i permesa era el castellà, cosa que li feia gaudir d'un prestigi excepcional per damunt de qualsevol altra llengua a l'estat espanyol.

Així, en els llibres de festes de 1974 i 1976 trobem quatre composicions en versos lliures que tenen com a nucli temàtic la mar.

L'any 1974 publica «Preludi exaltat a Cullera en Festes». La mar provoca per a Maria Mulet en les criatures que la contemplen un «desig de mar al cor» i exclama admirada: «intentem d'alçar la mar feta poesia».

Recordem que havia estat mestra al Colegio de Orientación Marítima, on la majoria de les famílies dels seus alumnes vivien de la producció marinera i ella se sentia estretament lligada a aquest món amb els seus problemes i els seus delers:

Oh tot allò meu, que és viure entre remor, paraules, ulls, mans, gests de mariners, de pescadors, de xiquests i xiquetes de la mar; entre xarxes esteses al sol, o veles arribant de la mar pel riu Xúquer! Oh, tots nosaltres valencians, cara a la mar,

REVISTA VALENCIANA DE FILOLOGIA / IV (2020) p. IO9-I33 ENCARNA VILLAFRANCA GINER Maria Mulet, escriptora i docent (1911-1982) / I 22 
Fent-ne pregó d'ell!

Per aquesta ventura que féu els nostres dies

Formosos: gràcies, MAR!.

També el mateix any 1974 publica un poema de caràcter religiós: «Mar, Mare de l'Encarnació». La Mar esdevé la Mare de l'Encarnació protectora de la vida dels homes de la Mar i de la subsistència econòmica de moltes famílies que en depenen a Cullera. La Mar, la Mare... pren vida en la cançó i és la seua veu la que s'escolta, però si no fora pel títol no pensaríem que és un poema dedicat a la Mare de Déu.

[...]

-Perquè sóc barca, perquè sóc rems, perquè sóc llum, perquè sóc xarxes, perquè sóc peixos, record, enyor, cor. Ai! Que sóc cor obrint miracle, posant-me endins $[\ldots]$.

En el llibre de festes de 1976 podem llegir dues composicions, «Plàcida tarda d'estels. Cançó de bres per a la mar» i «Ocell ple de mar. Un encontre», totes dues de caire pairalista, on la mar torna a ser el motiu del poema.

L'ocell està esbalaït no sap què li passa avui.

L'ocell no havia dit mai aquest tros blau és la mar.

Vola, Escampa les ales tremoloses, (ai! escampar així les ales; és amor?)

REVISTA VALENCIANA DE FILOLOGIA / IV (2020) p. IO9-I33 
Canta,

Canta com mai (amunt, quasi és àngel!)

(ai! cantar així i la seua cançó: és amor?)

S'ompli de llum, llum. Es un tros de llum, (ai! lluir, ser tros de llum; és amor?)

$[\ldots]$.

\subsubsection{Els llibres en valencià}

Veus de Xiquets (1971), llibre de poemes infantils publicat per les $\mathrm{Pu}-$ blicacions dels Cursos de Llengua i Literatura Valenciana de LRP el 1975, tingué tres edicions. Aquest llibre està dedicat a Carles Salvador, del qual diu en la dedicatòria:

Fou un meravellós valencianista — fill del barri del Carme- valencià pels quatre costats. Fou excels.

La seua poesia no morirà: València és agraïda sempre.

Tot seguit trobem un pròleg de Martí Domínguez amb el títol «Com un pa», on posa de manifest la condició infantil del llibre i també la vocació de mestra de l'autora.

Per a la sensibilitat d'una dona com Maria Mulet la poesia és més que Art; és un pa. [...] Maria Mulet, amb un gran pa a les mans, és essencialment, una innata convidadora.

[...] Ara fidel a la seua vocació i professió, ens dóna este manoll de poemes: Veus de Xiquets. Versos menuts, per als menuts, d'una mestra valenciana, i dedicats a un gran mestre valencià i del valencià. Carles Salvador, gran convidador també, comprenia com ningú aquesta petita proesa.

El llibre està dividit en dotze parts, cadascuna de les quals va encapçalada per un text en prosa on l'autora es dirigeix directament al lector jove per tal d'introduir-lo en la temàtica dels poemes. 
És important la part dedicada a «Cançons marineres», quatre poemes on la mar i els mariners esdevenen, de nou, el punt de mira de la poeta:
Voldria ser mariner
i tindre els peus en la mar
acaronant la voreta.
Voldria tindre una barca
per a poder navegar $[\ldots]$.

El component religiós en la poesia de Maria Mulet es fa patent en aquest llibre en parts com «A la Verge Maria!» o «Nadalenques».

El llibre inclou un vocabulari bàsic, la qual cosa demostra la seua voluntat pedagògica.

-Nadal al cor, poemes per a tots (1973), fou també publicat per les Publicacions dels Cursos de Llengua i Literatura de LRP. Aquest llibre consta de quatre parts amb una introducció i un epíleg. "Justifique el meu entusiasme» ens introdueix en el que serà la temàtica global de l'obra, el Nadal, com també el goig que té l'autora en aquestes dates; i ens mostra la seua vivència personal a l'escola marinera de Cullera: «[...] El nostre Ninet ací és sempre mariner ho sabem. Ha de ser així perquè així el sentim al cor».

Tot seguit comença amb una part dels poemes encapçalada per un text en prosa, «Ja estan anunciats», on s'exposen els plantejaments temàtics del llibre una altra vegada. Els poemes que segueixen el text giren al voltant de l'Anunciació i el naixement de Crist i se centren en la figura de Maria. La segona part, «Ve Jesús al món", consta d'un text en prosa en què se'ns diu el perquè del naixement del Salvador. Els poemes versen sobre les manifestacions d'adoració que mostren les gents més planeres cap al Jesuset, com també l'alegria generalitzada que pren el món en nàixer el «Ninet». La tercera part del llibre porta per títol «I altres paraules», en què el text en prosa que precedeix els poemes exhorta a pregar al Jesuset per la Pau. El segueix un altre text en prosa titulat «Sagrada Família», en el qual Maria Mulet ens presenta la família de Natzaret. Els poemes són una visió

REVISTA VALENCIANA DE FILOLOGIA / IV (2020) p. IO9-I33

ENCARNA VILLAFRANCA GINER

Maria Mulet, escriptora i docent (1911-1982) / I 25 
particular de la família de Jesús; com també del camí d'emigració fugint del rei Herodes. L'última part «Alça't, Betlem, que és hora... A viatjar! Betlem obeeix!» ens explica que ara el Betlem se'n va a València, i centra tots els poemes en terres valencianes, concretament a la Ribera, com ho demostren els següents fragments:

«Ninet mariner»

—¿Què vindrà el Ninet

a l'Escola?

-És clar que vindrà

i dormirà en la barca

que li hem preparat.

«Deler» (A Albalat de la Ribera)

Als Reis...

Els eixien les paraules

com una oració senzilla.

Eren els tres llauradors

més alts que al poble hi havia,

—això era l'important.

En això se distingia

$i$ estava content el poble.

«Nadala del riu Xúquer» (quan aplega a Cullera parla amb el cel)

I acaba amb un epíleg convidant «tots els hòmens de bona voluntat» a viure el Nadal.

3.2.3. Narrativa infantil. De Pedro, diario de un niño (1956) a Pere, diari d'un xiquet (1978), evolució de l'autora?

Quizá un niño de verdad sería el crítico más adecuado para un libro como Pedro. Un lector de cierta edad únicamente puede permitirse, a su propósito, reflexiones vagas y sin excesivo valor. Por otra parte, la autora se ha propuesto un fin pragmático, que sobrepasa los límites —mis límites, ahora- de lo literario: educar, y educar de acuerdo con principios, anécdotas

REVISTA VALENCIANA DE FILOLOGIA / IV (2020) p. IO9-I33

ENCARNA VILLAFRANCA GINER

Maria Mulet, escriptora i docent (1911-1982) / I 26 
o slogans que uno, desde luego, no comparte. Pero lo que aquí interesa, en realidad es el instrumento de que Maria Mulet se ha servido para ello: la gracia de una prosa sutil, la seducción de unos versos de dócil musicalidad —letrillas airosas, casi atribuibles a la voz anónima del pueblo—, el sentido de lo infantil plenamente captado... Pedro está, sin duda, destinado a ganarse muchos amigos por su gesto decidido por su vida deliciosa.

Així definia Fuster, el 13 de novembre de 1956 des de les pàgines del Levante el llibre que acabava de publicar a València per Editorial Bello Maria Mulet: Pedro, diario de un niño.

Pedro o Pere, és el personatge central i narrador protagonista del llibre més conegut de Maria Mulet, situat a la vora del Xúquer, al poble d'Albalat de la Ribera, que esdevé el medi on es mou el nostre personatge infantil, qui se'ns presenta com un gran descobridor del món que l'envolta i un gran vividor, especialment sensible als senzills successos quotidians del seu entorn.

Pedro, diario de un niño (1956) fou traduilt per Maria Mulet i publicat en valencià el $1978 \mathrm{amb}$ el títol Pere, diari d'un xiquet. La versió traduïda ens permet observar unes variacions prou considerables pel que fa a les consideracions d'alguns dels temes que aborda l'escriptora al seu llibre.

Així de Pedro... a Pere... trobem uns canvis prou significatius pel que fa a la ideologia que mostra el llibre de 1956. Aquest fet és el que Fuster anomena, en la seua ressenya, "slogans que uno, desde luego, no comparte», aquests eslògans són tres capítols del llibre titulats «20 de noviembre: José Antonio (¡Sacrificio!)», «El señor cura es muy bueno» i «Víspera de la fiesta de la Victoria», els quals són eliminats a la versió traduïda al valencià de 1978. Cal dir que en cap altra de les seues obres apareixen aquests tipus exaltacions.

\subsubsection{Docent i escriptora: a partir de Pere, diari d'un xiquet (1978)}

El diari és, en aquest cas, el gènere emprat per l'autora per tal de crear un llibre adreçat a una població infantil on el mateix protagonista i narrador se'ns presenta de manera implícita com a model de comportament social i cívic. El

REVISTA VALENCIANA DE FILOLOGIA / IV (2020) p. IO9-I33

ENCARNA VILLAFRANCA GINER

Maria Mulet, escriptora i docent (1911-1982) / I 27 
diari com a gènere autobiogràfic provoca en el lector la curiositat d'endinsar-se en la intimitat i privacitat de qui escriu. I així, l'autora es dirigeix al lector model amb la finalitat de mostrar un nen model a seguir, a qui pretén que el lector prenga com a model en la vida.

Pere, un xiquet senzill, d'una família de llauradors, que podria ser qualsevol alumne de qualsevol escola de l'època, fa verídica la seua història contant-la en primera persona, un personatge pròxim, arrelat al medi, coneixedor de l'orografia de l'entorn, interessat per la seua llengua, que llig i s'interessa per la cultura. Tot plegat pot provocar en els lectors una identificació que té la capacitat d'educar d'acord amb allò que la gent una mica més gran pretén, i es troba en la línia de la moral predominant de l'època.

L'escriptora, doncs, accentua la part més càndida i innocent de l'infant, l'explota al màxim i, en canvi redueix al mínim la malícia del jove. Pere comença el seu diari dient-nos:

Després, com que voldré escriure coses bones, caldrà fer-les bones. Bon comportament, com diu el meu mestre... [...] «Fer coses bones! ¡Voler ferles! ¡Intentar-ho! Només caldrà un comportament mesurat.

També hi veiem com el nostre protagonista està interessat en la bona educació: ${ }^{6}$

Ser un xiquet educat és fàcil. [...] Açò li ho oïa dir a ma güela (sic) moltes voltes. Potser tractava de corregir-nos les faltes comeses.

Dic tota la veritat; estic content de contar esta veritat... (p. 30)

Ordre de fer desaparéixer tots els rifles i les pistoles.

Que els xiquets no agafen mistos.

Que no vagen a nadar a soles al riu, i mai després de dinar; ni jo tampoc.

Que no córregen en les bicicletes com a folls, sense mirar el perill, ni jo tampoc. Els menuts deuen obeir...; i jo, també.» (p. 61).

6 Pere, diari d'un xiquet (1973: 41).

REVISTA VALENCIANA DE FILOLOGIA / IV (2020) p. IO9-I33

ENCARNA VILLAFRANCA GINER

Maria Mulet, escriptora i docent (1911-1982) / I28 
A més, Pere té una gran estima pels llibres: "A tots ens agraden els llibres i quan ens reunim, mai no perdem el temps en altres coses que no siga estudiar...»(p. 40).

Però no és ací on flueix la veu de la mestra que ensenya. Ho fa i amb més força, si ho observem, en el tipus d'ensenyament que rep Pere o en les coses que manifesta el mestre que s'han de saber. Així, Pere estudia i s'entusiasma per l'art pictòric: Sorolla, Segrelles, Joan Ribera... són explicats a classe per Don Joan, el mestre, i cal afegir que el coneixement del nostre passat cultural sembla prou important per al mestre d'Albalat de la Ribera:

[...] el castell de Xàtiva, i la muralla..., del teatre romà de Sagunt, de Penyíscola; i de València ciutat, les Torres de Quart i les de Serrans; i també El Palmeral i la Dama d'Elx..., l'arc d'estil romà en Cabanes...

A més, Pere i els seus amics rebien i enviaven cartes periòdicament a altres escoles de la província de València i de vegades fins i tot feien excursions a la mateixa capital per a conéixer de prop la ciutat. ${ }^{7}$ I encara, Pere manifesta la seua opinió sobre el fet que «cal que àdhuc la gent de fora aprenga a parlar la nostra llengua» (p. 121).

L'observació directa de la natura l'atrau molt, així, després d'una classe de geografia, fa una descripció directa del riu que passa pel poble, el Xúquer, el qual, segons el pare de Pere, és «font de riquesa».

Pere, preocupat per la bona educació i el comportament humà, recull en el seu diari frases fetes i refranys propis de les nostres terres que sent dir als seus majors: «El que bé obra bé cobra», «Qui bé et vol et farà plorar»... (p. 33).

Com veiem Pere, diari d'un xiquet és un compendi de geografia, llengua i cultura. D'aquesta manera Maria Mulet vol despertar en l'alumnat interés per la seua llengua i la seua cultura.

7 Pere, diari d'un xiquet (1973: 41).

REVISTA VALENCIANA DE FILOLOGIA / IV (2020) p. I09-I33

ENCARNA VILLAFRANCA GINER

Maria Mulet, escriptora i docent (1911-1982) / I 29 


\section{Conclusions}

Maria Mulet, com a mestra i com a escriptora, va mantenir una consonància amb la societat establida pel règim, arrelada a l'ambient oficial i a les formes imperants. Ara bé, el fet de ser fadrina li donà una certa llibertat i li permeté desenvolupar la seua vocació de mestra i d'escriptora. Va gaudir de l'avantatge de tenir un ambient familiar intel-lectual i d'estar relacionada amb personatges del valencianisme polític i intel-lectual de preguerra.

A mesura que avançaven les tímides escletxes oberturistes del règim implementava en els seus mètodes pedagògics novetats que havien format part de les noves pedagogies anteriors a la Guerra Civil. I el mateix va fer amb l'evolució de la seua poesia.

Fou una escriptora bilingüe i escrigué en les dues llengües indistintament, tant per a un públic adult com per a un públic infantil. Els seus escrits presenten una mancança d'elements autobiogràfics però el medi natural que l'envolta esdevé el motiu central de moltes de les seues obres. Aquestes no són reivindicatives però sí que pren part pels més vulnerable del seu entorn social rural i mariner, el llaurador, el pescador i els xiquets i les xiquetes.

Per a definir-la com a mestra podem observar el personatge de Don Joan del llibre Pere, diari d'un xiquet..., el qual podria representar un alter ego de la nostra autora. En aquest personatge destaquen unes característiques poc usuals pel que fa a l'ensenyament a les aules de l'època: llibertat d'acció dels alumnes dins l'aula, la qual està proveïda fins i tot de material de laboratori, mapes...; foment del coneixement de l'entorn historicocultural del país, intercanvi de correspondència entre diverses escoles, idees pacifistes, valors humanistes i solidaris, etc. I, sobretot, la voluntat ferma d'ensenyar al seu alumnat la seua llengua materna però d'ensenyar en un valencià digne que es trobava exclòs de l'escola.

Maria Mulet i d'altres mestres canalitzaren la creació de recursos per altres vies alienes a la tasca docent oficial. Així, fomentaren la producció de textos en valencià, bé a través de publicacions locals, bé a través d'altres vies com Lo Rat Penat Llibres o les poques editorials que ho tenien permés. Intentaren,

REVISTA VALENCIANA DE FILOLOGIA / IV (2020) p. IO9-I33

ENCARNA VILLAFRANCA GINER

Maria Mulet, escriptora i docent (1911-1982) / I30 
doncs, una renovació silenciosa des de dintre del sistema escolar i literari, una actuació constructiva en la mesura en què el règim ho va permetre.

A més, en el cas que ens ocupa, Maria Mulet, escriure en valencià i produïa un gran entusiasme ja que es retrobà ella mateixa amb els seus orígens, amb les seues arrels: «Es más, estoy reuniendo el viejo vocabulario de mis abuelos y mis padres, que no lo tenía olvidado pero sí adormecido» (Arazo 1973).

Maria Mulet, en la seua obra, mostra una gran religiositat centrada en tres aspectes: d'una banda, l'entrega a l'altre, l'estima a la resta de germans en Déu en el sentit cristià del terme. I també, en la seua devoció a la Mare de Déu i la seua vivència del Nadal com la oportunitat que Déu dona per tornar a renàixer cada any, i ho explica perfectament en una entrevista amb motiu de la presentació del seu llibre Nadal al cor:

Yo creo que la Navidad es algo así como volver a empezar. El dedo de Dios nos toca y nos hace volver a nacer. Quedamos como resucitados, más sencillos, más limpios. Eso nos da ocasión de empezar de nuevo, para reformar nuestro interés por la vida, para recuperar nuestras fuerzas.

Des d'un punt de vista estètic, les seues formes, als anys seixanta i setanta, eren formes de creació antiquades que s'arrossegaven des de l'època de la Renaixença, marcada poèticament per Teodor Llorente.

Aquesta fossilització de formes té molt a veure amb la salut que gaudia la llengua i, de retruc, la literatura. Perquè les literatures que es nodreixen estèticament de la tradició repetint, sense parar, sense renovació, formes i conceptes no són més que llengües i literatures minoritzades.

Ara bé, des del punt de vista de la història lingüística de la segona meitat del nostre segle sí que és interessant. Aquesta poesia jocfloralesca se'ns mostra escrita en una llengua acurada i segueix la línia marcada per Carles Salvador i el grup de LRP.

Recordem com «en els primers anys del franquisme, la poesia fallera, ratpenatista anava en camí d'esdevenir l'única literatura que podia arribar als

REVISTA VALENCIANA DE FILOLOGIA / IV (2020) p. IO9-I33

ENCARNA VILLAFRANCA GINER

Maria Mulet, escriptora i docent (1911-1982) / I3 I 
lectors i ací justament la motivació de dos articles de Carles Salvador» (Cortés 1995: 229), en els quals el mestre propugna un retorn al llorentinisme per tal d'eliminar la vulgaritat i restaurar-la. Per tant, podem incloure o no Maria Mulet dins la colla de lletraferits que des del Cap i Casal intentaren «salvar els mots", però ningú no podrà negar que Maria Mulet fou una immediata i excel-lent receptora del missatge d'aquests valencianistes que realitzaren una dura tasca en un temps tan aspre.

Així les coses, Maria Mulet cal situar-la sense embuts en el segon grup d'escriptores en la classificació proposada per Maria Lacueva (2013), aquelles que viuen i coneixen els avanços socials de la República. D'altra banda, Matilde Llòria esdevindrà una escriptora trilingüe (Lacueva, 2013: 101), però escriu en valencià després de passar pel castellà igual que ho feu Maria Mulet. I amb Beatriu Civera compartirà el seu pas per LRP i la seua visió cristiana de la vida.

Doncs bé, i ja per a acabar, direm que Maria Mulet fou una de tantes dones silenciades, nascudes a principi de segle i que visqueren un canvi social després d'una guerra i en patiren les conseqüències. Ella va saber ben bé aprofitar tots els recursos que tingué a l'abast per a escriure i treballar. Només per aquests dos fets Maria Mulet fou una transgressora del seu temps ja que eren dues activitats molt allunyades d'aquelles destinades a les dones en una època tan difícil per a aquestes.

REVISTA VALENCIANA DE FILOLOGIA / IV (2020) p. IO9-I33

ENCARNA VILLAFRANCA GINER

Maria Mulet, escriptora i docent (1911-1982) / I32 


\section{Bibliografia}

Arazo, M. Á. (1973) «Diálogo con Maria Mulet», Las Provincias (18-12-1973).

Bernal, A.; Dolç, M. (1989) «El moviment poètic de la postguerra valenciana», Els Marges, 40, Barcelona.

СARbó, F.; Simbor, V. (1993) La recuperació literària de la postguerra valenciana (19391972), València - Barcelona, Institut de Filologia Valenciana / Publicacions de l'Abadia de Montserrat.

Cortés Carreres, S. (1995) València sota el règim franquista, Valencia / Barcelona, Institut de Filologia Valenciana / Publicacions de l'Abadia de Montserrat.

Fresquet, R. (1996) «Escrits en valencià als llibres de festes de Carcaixent entre 1962 i 1978», dins Martí Domínguez i el seu temps, Algemesí, Ajuntament d'Algemesí / Germania, pp. 171-188.

Fuster, J. (1980) Antologia de la poesia valenciana (1900-1950), València, Eliseu Climent editor. -

- (1995) Llegint i escrivint. Artículos periodísticos en Levante-EMV: 1952-1957, Barcelona, Editorial Prensa Ibérica.

Giménez Úbeda, J. R. (2003) Vicent Mulet, un pintor oblidat, Albalat de la Ribera, Ajuntament d'Albalat de la Ribera.

Lacueva, M. (2013) Elles prenen la paraula. Recuperació crítica i transmissió a les aules de les escriptores valencianes de postguerra: una perspectiva des de l'educació literària (tesi doctoral), Universitat de València.

Payeras Grau, M. (2009) Espejos de la palabra. La voz secreta de la mujer en la poesia espanyola de postguerra (1939-1980), Madrid, UNED.

Simbor, V. (1983): Carles Salvador i Gimeno: una obra decisiva, València, Diputació Provincial de València.

Villafranca, E. (1998) «Docència i escriptura a Cullera. Maria Mulet», dins II Jornades d'Estudis sobre Cullera, Ed. Germania.

REVISTA VALENCIANA DE FILOLOGIA / IV (2020) p. IO9-I33

ENCARNA VILLAFRANCA GINER

Maria Mulet, escriptora i docent (1911-1982) / I33 
